\title{
Cross-reactivity of Anti-yellowtail Thymic Lymphocyte Monoclonal Antibody (YeT-2) with Lymphocytes from Other Fish Species
}

\author{
Hitoshi Nishimura ${ }^{1}$, Masaru IKemoto ${ }^{2}$, Kenji KAWAI ${ }^{3}$ and Riichi KUSUda ${ }^{3}$ \\ Laboratory of Host Defense ${ }^{1}$, Research Institute for Disease Mechanism and Control, Nagoya University School of Medicine, \\ Nagoya; Laboratory of Marine Stock-Enhancement Biology ${ }^{2}$, Kyoto University, Graduate School of Agriculture, Kyoto; and Fish \\ Disease Laboratory ${ }^{3}$, Faculty of Agriculture, Kochi University, Kochi, Japan
}

Received December 17, 1996

Summary. The monoclonal antibody YeT-2, generated in mice hyper-immunized with thymic lymphocytes of the yellowtail, Seriola quinqueradiata, reacts with the major population of peripheral blood lymphocytes, which might be putative $T$ cells. In this study, we examined the cross-reactivity of YeT-2 with lymphocytes from various fish species. Flow cytometric analysis showed that YeT-2 reacts with $69.8 \%$ lymphocytes in the thymus, $89.7 \%$ in the peripheral blood, $87.5 \%$ in the spleen, and $59.7 \%$ in the head-kidney. Among the six fish species examined, only the red sea bream, Pagrus major, which is included in the same suborder Percoidei with the yellowtail, showed the presence of YeT-2 positive cells. Electron microscopic studies revealed that YeT-2 positive cells in the peripheral blood of the red sea bream were lymphocytes or unidentified leucocytes. Thymic lymphocytes of the red sea bream were also immunocytochemically stained with YeT-2. The molecular weight of the YeT-2 cross-reacting antigen on blood cells from the red sea bream was identical with that from the yellowtail, which was identified at approximately $115 \mathrm{kDa}$. These results suggest that the monoclonal antibody YeT-2 recognizes a conserved antigen on lymphocytes common to the red sea bream and yellowtail.

In the evolutional process of the adaptive immune system, the fish occupies in a critical position, as it is the most ancient group of vertebrates in which humoral and cellular immune systems work together as in mammals. One characteristic feature as a vertebrate is the presence of immunoglobulin. Fish immunoglobulin studied so far is generally similar to the mammalian IgM class although it is tetrameric in teleost fish, pentameric in other groups (MARCHALONIS,
1971), and monomeric in some other species (CLEM and MCLEAN, 1975). The occurrence of only one immunoglobulin class ( $\mu$ type) in most fish provides favorable experimental model for studying cellular recognition by immunoglobulin receptors and the subsequent immune response (VAN MUISWINKEL, 1982).

Another characteristic vertebrate feature is the presence of a major histocompatibility complex (MHC) antigen gene. The fish is the most primitive class of vertebrates because the capacity for acute allograft rejections can be demonstrated, suggesting the presence of the MHC antigen gene (see review in STET and EgBERTs, 1991). Two putative MHCs, class I and class II antigen encoding sequences have been reported in the carp, Cyprinus carpio (HASHIMOTO et al., 1990). A gene genome with a sequence that resembles the MHC class I $\alpha 3$ domains of higher vertebrates has been demonstrated in the shark, Ging. lymostoma cirratum (НАSHIMOTO et al., 1992). Furthermore, $\mathrm{T}$ cell receptor like genes were identified in the horned shark, Heterodontus francisci, which is phylogenetically the most primitive extant jawed vertebrate (RAST and LITMAN, 1994).

To identify fish $\mathrm{B}$ cells, monoclonal antibodies against serum immunoglobulin have been reported in the channel catfish, Ichtaluras punctatus (LOBB and ClEM, 1982), rainbow trout, Oncorhynchus mykiss (DeLuca et al., 1983), carp (SECOMBEs et al., 1983), and the giltherad sea bream, Sparus aurata (NAVARRO et al., 1993). On the other hand, a monoclonal antibody which distinguishes $T$ cells from $B$ cells has been obtained only in channel catfish by immunization of blood leucocytes (Miller et al., 1987), 
although the fish has a well developed, distinct thymus, suggesting the presence of functional $\mathrm{T}$ cells derived from the thymus (ETLINGER et al., 1976; WARR and SimON, 1983; ElLSAESSER et al., 1988). We previously reported that thymic lymphocytes from the yellowtail, Seriola quinqueradiata, have antigenically alternate properties with $\mathrm{T}$ cells, based on the cell surface receptors (NISHIMURA and KUSUDA, 1993). We also developed a monoclonal antibody against thymic lymphocytes in the yellowtail, YeT-2, characterized it by functional analysis, and concluded that the YeT-2 reacted with the major population of peripheral blood lymphocytes - which might be putative T cells (NISHIMURA et al., 1995). In this study, we aim to examine the cross-reactivity of YeT-2 against lymphocytes from other fish species.

\section{MATERIALS AND METHODS}

Fish

Yellowtail, Seriola quinqueradiata, weighing about $400 \mathrm{~g}$ cultured in Uranouchi Bay, Kochi Prefecture were used. Rainbow trout Oncorhynchus mykiss (70 g), red-spot masu trout Oncorhynchus masou macrostomus (60 g), ayu fish Plecoglossus altivelis (60 g), carp Cyprinus carpio (100 g), red sea bream Pagrus major $(150 \mathrm{~g})$, and Japanese flounder Paralichthys olivaceus $(200 \mathrm{~g})$ were kindly provided from a fish farm in Kochi Prefecture.

\section{Monoclonal antibody}

The monoclonal antibody YeT-2 was raised against yellowtail thymic lymphocytes. Details for establishing YeT-2 have been reported previously (NISHIMURA et al., 1995). The hybridoma producing YeT-2 was cultured in RPMI 1640 medium (Nissui Pharmaceutical, Tokyo, Japan) at $37^{\circ} \mathrm{C}$ under $5 \% \mathrm{CO}_{2}$, and the antibody containing supernatant was used for analysis.

\section{Preparation of yellowtail cells for analysis}

Peripheral blood leucocytes were separated from $2 \mathrm{ml}$ of heparinized blood with Ficoll-paque (Pharmacia Biotech., Uppsala, Sweden). The thymus, spleen and the head-kidney were independently minced with scissors in an L-15 medium (Flow) supplemented with $5 \%$ fetal calf serum (FCS), and single cell suspensions were obtained by passage through a stainless mesh (\#200). The cells were left in a plastic tissue culture dish for $1 \mathrm{~h}$ at room temperature, and the non-adherent cells were used for the separation of leucocytes. As for the cell suspensions of the spleen and head-kidney, lymphocytes were further separat- ed from the other leucocytes by density gradient centrifugation using a Percoll of density 1.065 (Pharmacia). These cells were washed three times with the L-15 medium before being used in the flow cytometric analysis.

\section{Flow cytometric analysis}

Lymphocyte suspensions of $5 \times 10^{6}$ cells $/ \mathrm{ml}$ in the L-15 medium containing $0.05 \% \mathrm{NaN}_{3}$ were incubated with the monoclonal antibody YeT-2 for $30 \mathrm{~min}$ on ice. After washing three times with the L-15 medium, an equal volume of diluted solution of FITCconjugated goat anti-mouse IgM antibody ( $\mu$ chain specific, Cappel Research Products, Durham, NC) was added. After $30 \mathrm{~min}$ of incubation on ice, the cells were washed 3 times. An analytical flowcytometer EPICS 752 (Coulter Co., Miami, FL) was used for this study. Lymphocytes were distinguished from other cells by setting a gate on the side scatter and light scatter detector, and 20,000 lymphocytes were analyzed from each cell fraction. Analysis was done using an argon-ion laser (488 $\mathrm{nm}$ emission) at a constant power of $500 \mathrm{~mW}$. Negative control was carried out by the same process without incubating YeT-2. Positive cells were recognized by a higher fluorescence intensity than that of the negative control.

\section{Thymic lymphocyte aggregation assay}

The aggregation assay by MASSELLIS-SMITH et al. (1990) was conducted with the following modifications. Cell suspension of thymic lymphocytes from six fish species and the mouse were adjusted to a concentration of $2 \times 10^{6}$ cells $/ \mathrm{ml}$ in the L- 15 medium, and 0.1 $\mathrm{ml}$ cells were added to $1.5 \mathrm{ml}$ tubes containing either $0.1 \mathrm{ml}$ of YeT-2 or an isotype control mouse IgM. Tubes were incubated for $1 \mathrm{~h}$ at room temperature and cells were mixed by pipetting. The microliters of cell suspension was transferred to a hemocytometer. Aggregation of the lymphocytes was assessed under a light microscope (Nikon, Tokyo, Japan).

\section{Ultrastructural immunocytochemistry}

Twelve well tissue culture plate (Coster, Cambridge, MA) containing $1 \times 10^{7}$ thymic or peripheral leucocyte suspensions in $1 \mathrm{ml}$ of the IL-15 medium in each well were centrifuged for $5 \mathrm{~min}$ at $350 \times \mathrm{g}$ at $4^{\circ} \mathrm{C}$. The supernatant was discarded and the monolayer cells were incubated for $45 \mathrm{~min}$ at $0^{\circ} \mathrm{C}$ with $1 \mathrm{ml}$ PBS supplemented with $10 \% \mathrm{FCS}$, in order to block nonspecific binding capability to the bottom of the wells. After the blocking solution was removed, the monolayer cells were incubated for $1 \mathrm{~h}$ at $0^{\circ} \mathrm{C}$ with $1 \mathrm{ml}$ of the diluted YeT-2, then washed three times with PBS containing $0.05 \% \mathrm{NaN}_{3}$ and $1 \%$ bovine serum albu- 
min, followed by incubation with $200 \mu 1$ of $20 \mathrm{~nm}$ gold conjugated goat anti-mouse IgM antibody (Zymed Laboratories, Inc., San Francisco, CA) for $1 \mathrm{~h}$ at $0^{\circ} \mathrm{C}$. During the incubation, plates were swirled every 10 min. After washing three times with a buffer solution, the cells were finally resuspended by vigorous pipetting. After centrifugation of the cell suspention at $350 \times \mathrm{g}$, the pellet of cells was fixed with $2 \%$ gultaraldehyde in $0.1 \mathrm{M}$ sodium cacodylate buffer, $\mathrm{pH} 7.2$, for $1 \mathrm{~h}$ and with $1 \% \mathrm{OsO}_{4}$ and for another $1 \mathrm{~h}$ on ice. The pellet was dehydrated in ethanol, cleared in propylene oxide and embedded in Epon Spurr (TAAB Laboratories Equipment Ltd., Berkshire, UK). Ultrathin sections were made using an Ultra Cut N (ReichertNissei, Vienna, Austria). They were stained with uranyl acetate and lead citrate and observed in an electron microscope JEM-100s at $80 \mathrm{kV}$ (JOEL, Tokyo, Japan). Characterization of different leucocyte types was made on the basis of morphologic criteria described by GORGOLLON (1983) and LOPEZ-RUIZ et al. (1992).

\section{Western blotting}

The molecular weight of the antigens recognized by the monoclonal antibody was determined by Western blotting according to the method by CHUNG et al. (1991). In brief, $1 \times 10^{7}$ leucocytes were suspended in PBS, pH 7.2. The cell suspension was sonicated for 30 sec on ice and centrifuged at $500 \times \mathrm{g}$ for $5 \mathrm{~min}$. The supernatant was collected and resuspended in a reducing Laemmli sample buffer for SDS-PAGE (LAEMMLI, 1970). The sample was heated in a boiling water bath for 5 min, loaded on to $4.5 \%$ stacking/ $12.5 \%$ resolving gel of $1 \mathrm{~mm}$ thickness and electrophoresed at $0.38 \mathrm{~mA} / \mathrm{mm}$ constant current. The separated proteins were then transblotted from the gel to a Trans-Blot Transfer Medium (Bio-Rad Laboratories, Hercules, CA) for $20 \mathrm{~min}$ at $20 \mathrm{~V}$ constant voltage using Transblot SD (Bio-Rad). After transblotting, the protein-impregnated nitrocellulose membrane was stained by a conventional method using enzyme immunoassay.

\section{RESULTS}

\section{Flow cytometric analysis}

Similar to mammalian ecotaxis (DESouSA, 1981), some populations of fish lymphocytes appeared to migrate through the thymus, and then to the peripheral lymphoid organs (TATNER and FindLAY, 1991). To examine whether the YeT-2 can recognize the T lymphocytes in the peripheral lymphoid organs, flow cytometric analysis was carried out using lymphocytes in the peripheral blood, spleen, and head-kidney (Fig. 1). The percentages of YeT-2 positive cells are as follows (mean \pm standard deviation): $88.9 \% \pm 1.8$ of peripheral blood lymphocytes, $76.1 \% \pm 8.9$ of thymic lymphocytes, $85.4 \% \pm 9.0$ of splenic lymphocytes $58.2 \% \pm 5.4$ of head kidney lymphocytes. The fluorescence intensity of YeT-2 positive thymic lymphocytes varied from weak to high, while YeT-2 positive cells in the peripheral blood, spleen, and head-kidney showed only a weakly positive intensity. The nonspecific binding of a negative control was less than $2 \%$ throughout the studies.

\section{Cross-reactivity against lymphocytes from other fish species}

Teleosts are the vertebrate group with the highest number of species. We examined the cross-reactivity

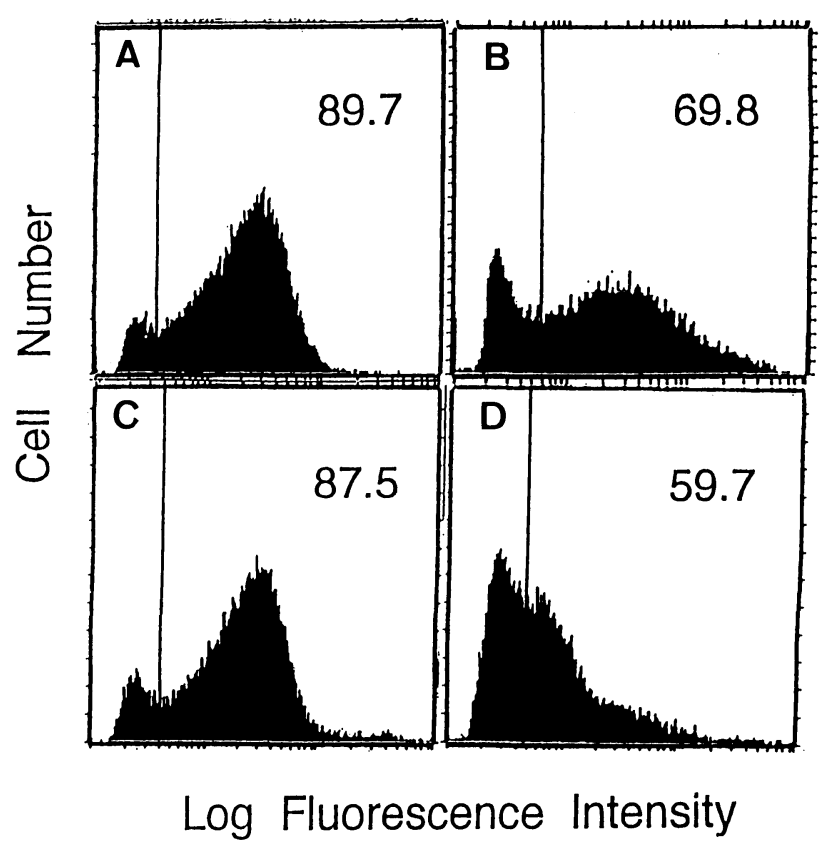

Fig. 1. Flow cytometric analysis of lymphocytes in the peripheral lymphoid organ of the yellowtail by anti-yellowtail thymic lymphocyte monoclonal antibody YeT-2. Lymphocytes are distinguished from other cells by setting a gate on the side scatter and light scatter detector, and 20,000 lymphocytes have been analyzed from each cell fraction. Each represents data from the peripheral blood (A), thymus (B), spleen (C) and head kidney (D). Values in $\mathbf{A}, \mathbf{B}, \mathbf{C}$ and $\mathbf{D}$ show the positive percentages. The area left of middle lines indicates negative fraction. 

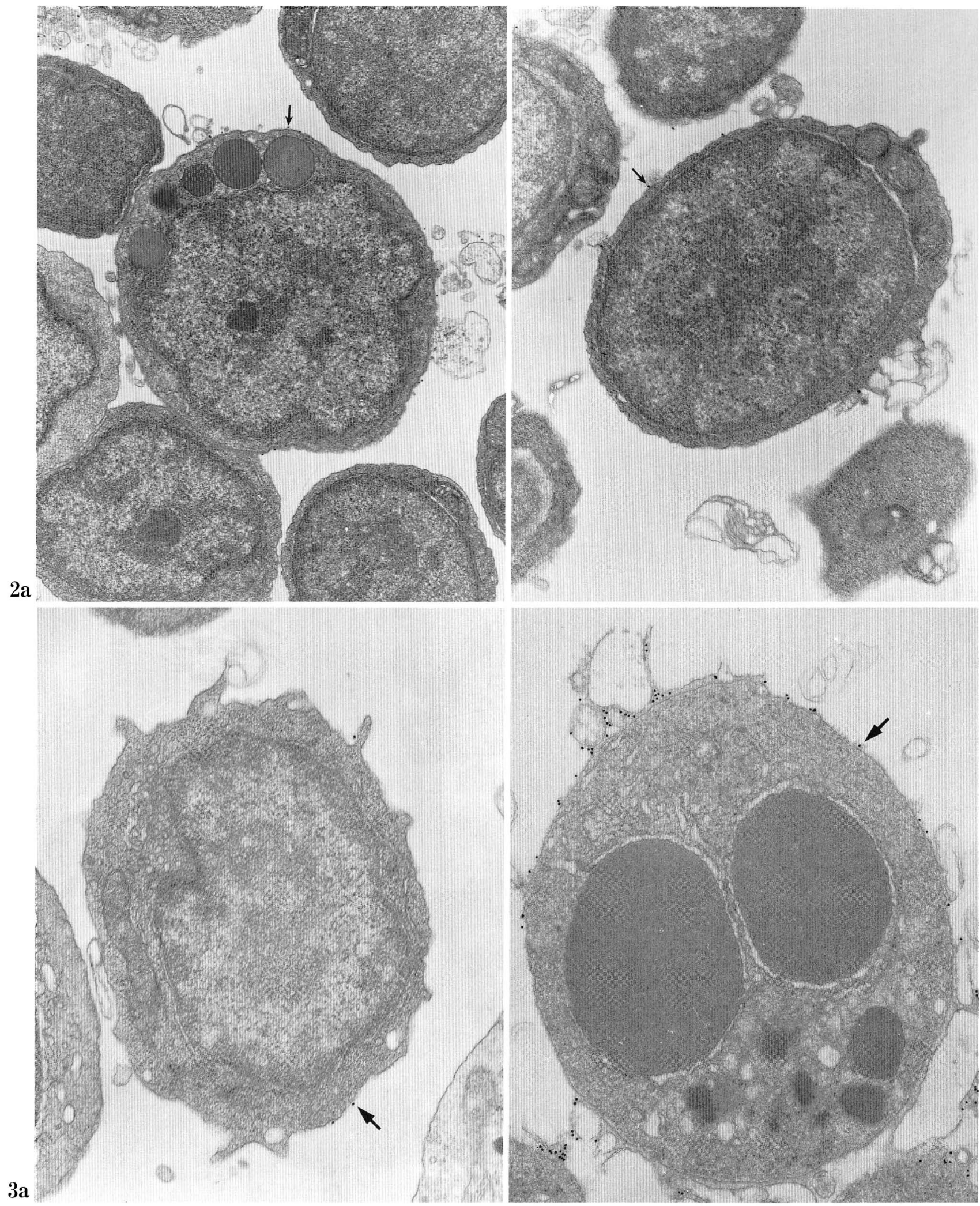

Figs. 2 and 3. Legends on the opposite page. 
of YeT-2 with thymic lymphocytes from rainbow trout, red-spot masu trout, ayu fish, carp, red sea bream and Japanese flounder as assessed by lymphocyte aggregation assay. Among them, only the red sea bream showed the presence of YeT-2 positive cells. Electron-microscopically YeT-2 positive cells in the peripheral blood of the red sea bream shared ultrastructural features with YeT-2 positive thymic lymphocytes of the yellowtail and red sea bream (Figs. 2, 3a). These cells also displayed typical characteristics of lymphocytes according to the criteria by GORGOLLON (1983) and Lopez-Ruiz et al. (1992). The cells were round with a few short cytoplasmic processes and contained a large, central, round or indented heterochromatin-rich nucleus. Their scarce cytoplasm contained a few large mitochondria, numerous free ribosomes, and some clear vesicles. The number of immune gold particles was usually less than 5 particles per peripheral blood lymphocyte. In addition, there were ultrastructurally unidentified leucocytes which reacted with YeT-2 in the peripheral blood of red sea bream (Fig. 3b). The cytoplasm contained a few granules which were round in shape, homogeneously electron-dense, and measured $0.6-1.2 \mu \mathrm{m}$ in diameter. The number of immune gold particles on these cells was more than 40 particles. Although unidentified leucocytes similar in structure to those of the red sea bream were present in the peripheral blood of the yellowtail, YeT-2 did not react with these cells (data not shown).

\section{Determination of molecular weight by Western blotting}

To determine the molecular weight of the YeT-2 cross-reacting antigen on the cells of the red sea bream, we carried out Western blotting analysis using cell extract of red sea bream leucocytes (Fig. 4). The molecular weight of the antigen on blood cells from the red sea bream was identified at approximately $115 \mathrm{kDa}$, which was identical with that of the yellowtail. However, the extra-bands at approximately $100 \mathrm{kDa}$ and $45 \mathrm{kDa}$ were observed in peripheral blood leucocytes of the red sea bream. The isotype control (normal mouse IgM) did not specifically bind to any protein (data not shown).

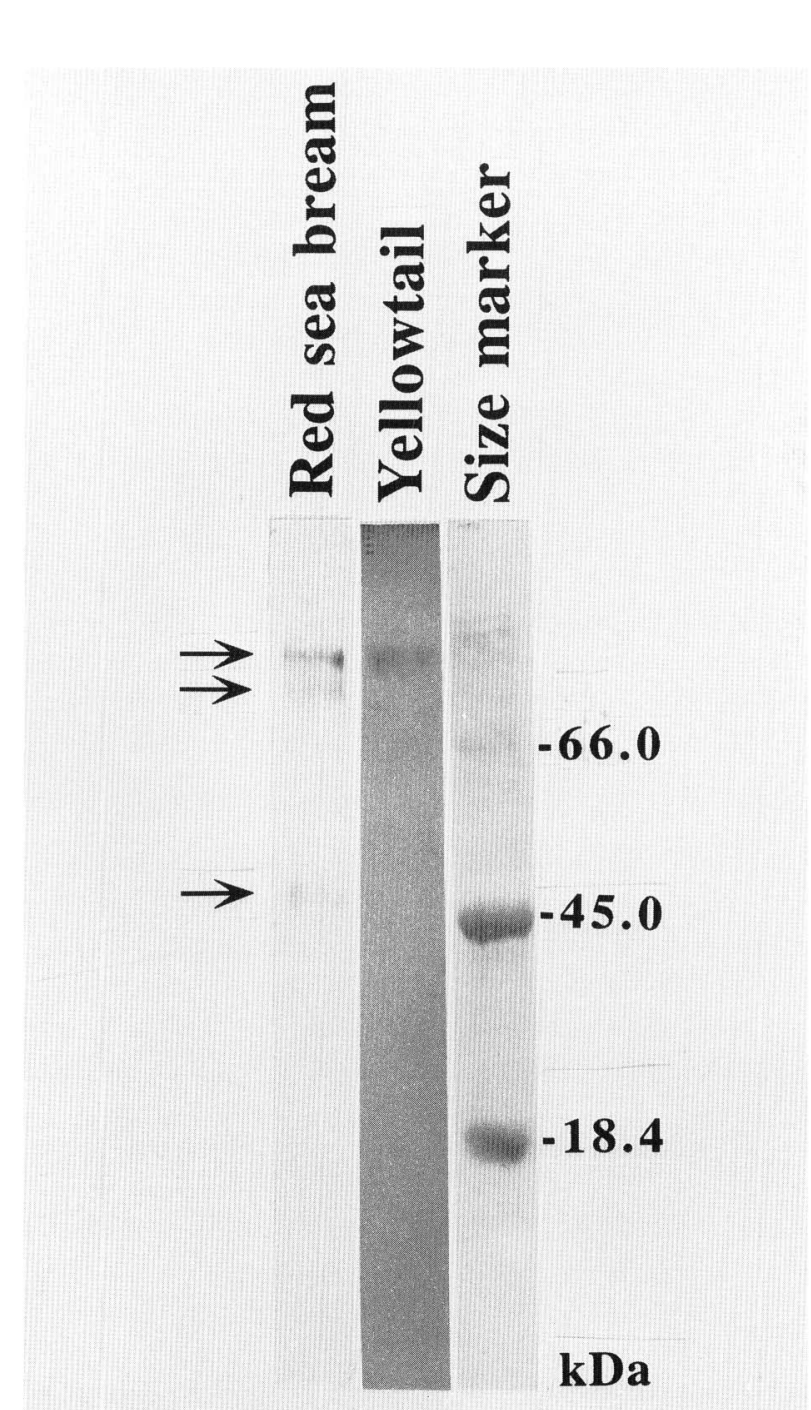

Fig. 4. Western blotting of the cell extract of peripheral blood leucocytes from the red sea bream or yellowtail. Cell extract from $1 \times 10^{7}$ leucocytes in a reducing sample buffer for SDS-PAGE loaded on to $4.5 \%$ stacking/12.5\% resolving gel and transblotted. After transblotting, the protein-impregnated nitrocellulose membrane was stained with the YeT-2. Each lane represents red sea bream, yellowtail and size marker. Arrows indicate positive bands of leucocytes from the red sea bream at the molecular weights of $115 \mathrm{kDa}, 100 \mathrm{kDa}$ and $45 \mathrm{kDa}$, respectively.

Fig. 2. Electron micrograph of YeT-2 positive lymphocytes in the thymus of the yellowtail (a) and red sea bream (b). Arrows indicate $20 \mathrm{~nm}$ gold particles. a: $\times 11,000, \mathrm{~b}: \times 15,000$

Fig. 3. Electron micrograph of YeT-2 positive lymphocytes in peripheral blood of the red sea bream. a: lymphocyte, b: unidentified leucocyte. Arrows indicate $20 \mathrm{~nm}$ gold particles. a, b: $\times 16,000$ 


\section{DISCUSSION}

We have examined the cross-reactivity of YeT-2 against lymphocytes from other fish species and found that the red sea bream Pagrus major, which is included in the same suborder Percoidei with the yellowtail, showed the presence of YeT-2 positive cells. Our electron microscopic studies have also revealed that Yet-2 positive cells of the peripheral blood in the red sea bream were morphologically identified as lymphocytes except for the presence of some unidentified leucocytes. The molecular weight of the YeT-2 cross-reacting antigen on blood cells from the red sea bream was identical with that of the yellowtail. These results suggest that the Yet-2 recognizes a conserved antigen on lymphocytes common to the red sea bream and yellowtail. However, two extra-bands at approximately $100 \mathrm{kDa}$ and $45 \mathrm{kDa}$ in the red sea bream in Western blotting analysis remain a matter under consideration. Since the YeT-2 positive unidenthfied leucocytes were present only in the red sea bream, it is possible that the YeT-2 antigens at $100 \mathrm{kDa}$ and $45 \mathrm{kDa}$ are expressed on the surface of non-lymphoid cell, such as the leucocytes. Further study is needed to characterize the YeT-2 crossreacting antigen in red sea bream on the molecular basis.

The monoclonal antibody YeT-2 is valuable in the study of immune cells of the yellowtail, since it reacts specifically with $\mathrm{T}$ cells except for the cross reaction with granulocytes. It is true that several monoclonal antibodies against fish lymphocytes have been reported by previous authors. Monoclonal antibody $13 \mathrm{C} 10$ against catfish $\mathrm{T}$ cell-like lymphocytes, however, cross-reacts with thrombocytes, neutrophils and some brain cells (MiLLER et al., 1987). Anti-carp thymic lymphocyte monoclonal antibody WCT 23 recognizes molecules common to all leucocytes (SECOMBES et al., 1983; VAN DIEPEN et al., 1991). The monoclonal antibody against a trout peripheral blood leucocyte antigen (2PBL $4 \mathrm{X}$ ) binds a carbohydrate moiety broadly expressed in trout leucocytes (GREENLEE and RIsTOW, 1993). The monoclonal antibody DLT15 against thymic lymphocytes of the sea bass, Dicentrachus labrax, cross-reacts with a small percentage of lymphocytes in the peripheral blood, spleen and headkidney (SCAPIGLIATI et al., 1995). YeT-2 is much more efficient and specific than these monoclonal antibodies in respect to recognizing fish $\mathrm{T}$ lymphocytes. Interestingly, there are subsets of YeT-2 positive or negative lymphocytes in the thymus of the yellowtail. One possibility is that the YeT-2 antigen expression may depend on the developmental stage or activation levels of the thymic lymphocytes. However, it is necessary to investigate whether or not the expression levels on thymic lymphocytes changes according to thymic ontogeny.

The present study has clearly shown that YeT-2 positive cells occupy the major population of the lymphocytes in the peripheral blood, spleen and head kidney in the yellowtail. Similar to mammalian ecotaxis (DeSousa, 1981), TATner and Findlay (1991) showed that some populations of lymphocytes in the trout appeared to migrate through the thymus, and then to the peripheral lymphoid organs. Although the site of lymphopoiesis in fish have not been clearly established, our findings suggest that the phenomenon of ecotaxis occurs in fish as well as in mammals.

Acknowledgements. We thank Dr. S. Oshima for his review of this manuscript.

\section{REFERENCES}

Chung, K-S., H. S. LullehoJ and M. C. Jenkins: Avian leucocyte common antigens: molecular weight determination and flow cytometric analysis using new monoclonal antibodies. Vet. Immunol. Immunopathol. 28: 259-264 (1991).

Clem, L. W. and W. E. Mclean: Phylogeny of immunoglobulin structure and function. VII. Monomeric and tetrameric immunoglobulins of the margate, a marine teleost fish. Immunology 29: 791-796 (1975).

DeLuca, D., M. Wilson and W. G. WARR: Lymphocyte heterogeneity in the trout, Salmo gairdneri, defined with monoclonal antibodies to IgM. Eur. J. Immunol. 13: 546551 (1983).

DeSousa, M.: Circulation of lymphocytes within the lymphoid system. In: (ed. by) M. DESousA: Lymphocyte circulation. Chap. 4. John Wiley and Sons, ChichesterLondon, 1981 (p. 37-48).

Ellsaesser, C. F., J. E. Bly and L. W. Clem: Phylogeny of lymphocyte heterogeneity: the thymus of the channel catfish. Devel. Comp. Immunol. 12: 787-799 (1988).

Etlinger, H. M., H. O. Hodgins and J. M. Chiller: Evolution of the lymphoid system. I. Evidende for lymphocyte heterogeneity in rainbow trout revealed by the organ distribution of mitogenic response. J. Immunol. 116: 1547-1552 (1976).

Gorgollon, P.: Fine structure of the thymus in the adult cling fish Sicyases sanguineus (Pisces, Gobiesocidae). J. Morphol. 177: 25-40 (1983).

Greenlee, A. R. and S. S. Ristow: A monoclonal antibody which binds a carbohydrate moiety broadly expressed on rainbow trout leucocytes. Fish Shellfish Immunol. 3: 317-330 (1993).

Hashimoto, K., T. NAKANishi and Y. KuRosawa: Isolation of carp genes encoding major histocompatibility complex antigens. Proc. Nat. Acad. Sci. USA 87: 68636867 (1990). 

sequence resembling the major histocompatibility complex class I $\alpha 3$ domain. Proc. Nat. Acad. Sci. USA 89: 2209-2212 (1992).

LAEMmLI, U. K.: Cleavage of structural proteins during the assembly of the head of bacteriophage T4. Nature 227: 680-685 (1970).

LobB, J. C. and W. Clem: Fish lymphocytes differ in the expression of surface immunoglobulin. Devel. Comp. Immunol. 6: 473-479 (1982).

Lopez-Ruiz, A., M. A. Esteban and J. Meseguer: Blood cells of gilthead seabream (Sparus aurata L.): light and electron microscopic studies. Anat. Rec. 239: 161-171 (1992).

MARChALONis, J. J.: Isolation and partial characterization of immunoglobulins in goldfish (Carassius auratus) and carp (Cyprinus carpio). Immunology 20: 161-165 (1971).

Masellis-Smith, A., G. S. Jensen, J. G. Seehafer, J. R. SluPsky and A. R. E. Shaw: Anti-CD9 monoclonal antibodies induce homotypic adhesion of pre-B cell lines by a novel mechanism. J. Immunol. 144: 1607-1613 (1990).

Miller, N. W., E. J. Bly, F. VAN Ginkel, F. C. Elisaesser and W. L. Clem: Phylogeny of lymphocyte heterogeneity: identification and separation of functionally distinct subpopulations of channel catfish lymphocytes with monoclonal antibodies. Defel. Com. Immunol. 11: 739-747 (1987).

Navarro, V., J. A. Quesada, M. E. Abad, N. Taver NEAVERNE and J. H. W. M. RombouT: Immuno(cyto)chemical characterization of monoclonal antibodies to gilthead seabream (Sparus aurata) immunoglobulin. Fish Shellfish Immunol. 3: 167-177 (1993).

NishimuRA, H. and R. Kusuda: Cell surface receptors on thymocyte of yellowtail, Seriola quinqueradeata. Suisanzoshoku 41: 223-226 (1993).

Nishimura, H., N. Akamatsu, M. Ikemoto, K. Kawai, H. Miyazawa, S. Fujimoto and R. Kusuda: Monoclonal antibody against yellowtail thymic lymphocytes recognizing a lymphocytic subpopulation. Fish. Science 61: 181-185 (1995).

Rast, J. P. and G. W. Litman: T-cell receptor gene homologs are present in the most primitive jawed vertebrates. Proc. Nat. Acad. Sci. USA 91: 9248-9252 (1994).
Scapigliati, G., M. Mazzini, L. Mastrola, N. Romato and L. ABELLI: Production and characterization of a monoclonal antibody against the thymocytes of the sea bass Dicentrarchus labrax (L.) (Teleostea, Percicthydae). Fish Shellfish Immunol. 5: 393-405 (1995).

Secombes, C., J. J. M. VAN Groningen and E. Egberts: Separation of lymphocyte subpopulations in carp Cyprinus carpio L. by monoclonal antibodies: immunohistochemical studies. Immunology 48: 165-175 (1983).

STET, J. M. R. and E. EgBerts: The histocompatibility system in teleostean fishes: from multiple histocompatibility loci to a major histocompatibility complex. Fish Shellfish Immunol. 1: 1-12 (1991).

Tatner, M. F. and C. Findlay: Lymphocyte migration and localization patterns in rainbow trout Oncorhynchus mykiss, studied using the tracer sample method. Fish Shellfish Immunol. 1: 107-117 (1991).

Van Diepen, J. C., G. T. M. WagenaAR and J. H. M. RoмвоUT: Immunocytochemical detection of membrane antigens of carp leucocytes using light and eletron microscopy. Fish Shellfish Immunol. 1: 47-57 (1991).

Van Muiswinkel, B. W.: Fish immunology today. Devel. Comp. Immunol. Suppl. 2: 1-8 (1982).

WARR, W, G. and R. D. Simon: The mitogen response potential of lymphocytes from the rainbow trout (Salmo gairdneri) re-examined. Devel. Comp. Immunol. 7: 379384 (1983).

\author{
Hitoshi NishimuRa, Ph.D. \\ Laboratory of Host Defense \\ Research Institute \\ for Disease Mechanism and Control \\ Nagoya University School of Medicine \\ 65 Turumai, Showa-ku \\ Nagoya, 466 Japan \\ 西村 化志 \\ 466 名古屋市昭和区鶴舞町 65 \\ 名古屋大学医学部 \\ 病態制御研究施設 \\ 生体防御部門
}

